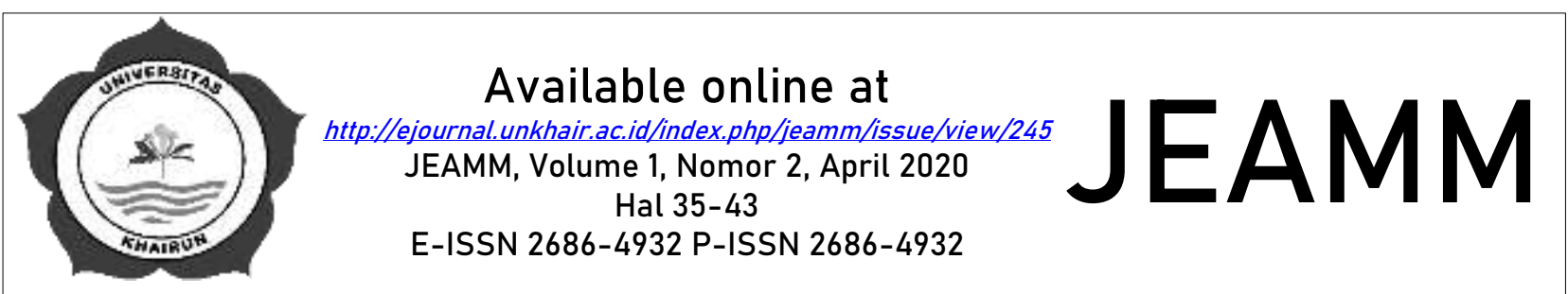

\title{
INFASI, PENGANGGURAN DAN KEMISKINAN DI PROVINSI MALUKU UTARA
}

\author{
Dewi Permatasari \\ Fakultas Ekonomi dan Bisnis Universitas Khairun \\ Email: dewipermatasaripedju@gmail.com
}

Dikirim, 8 Maret 2020

Revisi, 14 Maret 2020

Diterima, 27 Maret 2020

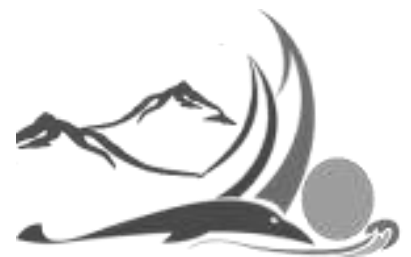

Jurnal Ekonomi, Akuntansi dan Manajemen

Multiparadigma

Volume 1, Nomor 2,

April 2020

\section{ABSTRAK}

Tinjauan kemiskinan dari dimensi ekonomi ini diartikan sebagai ketidakmampuan seseorang untuk mendapatkan mata pencaharian yang mapan dan memberikan penghasilan yang layak untuk menunjang hidupnya secara berkesinambungan. Kemiskinan merupakan salah satu masalah yang menjadi pusat perhatian di negara manapun. Kemiskinan disebabkan oleh berbagai faktor, seperti tingkat investasi yang masih dibawah standar, tingkat pengangguran yang tinggi, dan pertumbuhan ekonomi yang lambat. Tujuan penelitian ini adalah menganalisis pengaruh inflasi terhadap pengangguran dan kemiskinan, dan pengaruh pengangguran terhadap kemiskinan di Provinsi Maluku Utara. Penelitian ini menggunakan data runtun waktu (time series) tahun 2013-2018 dan menggunakan analisis jalur (path analysis). Hasil penelitian menunjukkan bahwa inflasi berpengaruh positif terhadap tingkat pengangguran dan kemiskinan di Provinsi Maluku Utara. Kemudian, pengangguran juga berpengaruh positif terhadap tingkat kemiskinan. Semakin tinggi tingkat inflasi dan pengangguran semakin besar tingkat kemiskinan.

Kata kunci: Inflasi, Pengangguran, dan Kemiskinan, Maluku Utara

\section{ABSTRACT}

Poverty review from the economic dimensions is interpretedas the inability of a person to obtain an established livelihood and provided a decent income to sustainably support life. Poverty is problems that attention any country. Poverty is caused by various factors, such as low investment, high unemployment, and slow economic growth. The purpose of this study was to analyze the effect of inflation on unemployment and poverty, and the effect of unemployment on poverty in North Maluku Provience. This study uses time series data from 2013 to 2018, and path analysis. The results showed that inflation has a positive effect on increasing unemployment and poverty. High unemployment has a positive impact on poverty levels. The higher level of inflation and unemployment, the higher poverty rate in the North Maluku Provience.

Keywords: Inflation, Unemployment, Poverty, North Maluku 


\section{PENDAHULUAN}

Kemiskinan dan pertumbuhan ekonomi merupakan indikator yang penting dalam mencapai keberhasilan pembangunan negara. Mencapai pembangunan, setiap negara akan berusaha keras untuk mengoptimalkan pertumbuhan ekonomi dan menurunkan tingkat kemiskinan. Munculnya permasalahan meningkatnya jumlah penduduk yang hidup dibawah garis kemiskinan terjadi di negara-negara berkembang termasuk Indonesia yang mengiringi tercapainya pertumbuhan ekonomi di negara-negara tersebut (Jonaidi, 2012). Kemiskinan merupakan masalah utama yang dialami oleh negara berkembang (Vincent, 2009). Kemiskinan berpengaruh besar terhadap angka pengangguran. Salah satu cara untuk keluar dari lingkaran kemiskinan adalah dengan menawarkan diri untuk masuk kedalam pasar kerja, dengan bergabungnya meningkat, sehingga seseorang tersebut bebas dari kemiskinan.

Menurunnya tingkat kemakmuran dan kesejahteraan dalam masyarakat disebabkan oleh tingginya tingkat pengangguran. Angka Kemiskinan dan Pengangguran biasa digunakan untuk melihat bagaimana tingkat kesejahteraan masyarakat. Mencapai kesejahteraan dan kemakmuran bagi seluruh masyarakat yaitu salah satu tujuan bangsa ini maka kemiskinan dan pengangguran menjadi sebuah komitmen bersama bagi seluruh komponen pemerintahan dan masyarakat untuk berupaya keras dalam penanggulangan masalah tersebut. Suatu negara dapat menghasilkan dampak negatif terhadap perekonomian negara disebabkan oleh tingginya tingkat pengangguran. Dampak dari pengangguran tidak hanya menjadi beban tersendiri namun juga berdampak pada pemeritah, keluarga maupun lingkungan dan lainlain (Amalia, 2012). Biasanya mereka yang dikategorikan miskin (the poor) tidak memiliki pekerjaan (pengangguran) karena juga bekaitan dengan keterbatasan pekerjaan. Pengangguran erat kaitannya dengan kemiskinan. Karena masih banyaknya masyarakat yang menganggur menyebabkan masalah kemiskinan terus meningkat. Angka kemiskinan selalu ada disebabkan oleh sebagian masyarakat masih banyak meganggur sehingga sulitnya dalam memenuhi kebutuhan hidupnya (Yudha, 2013).

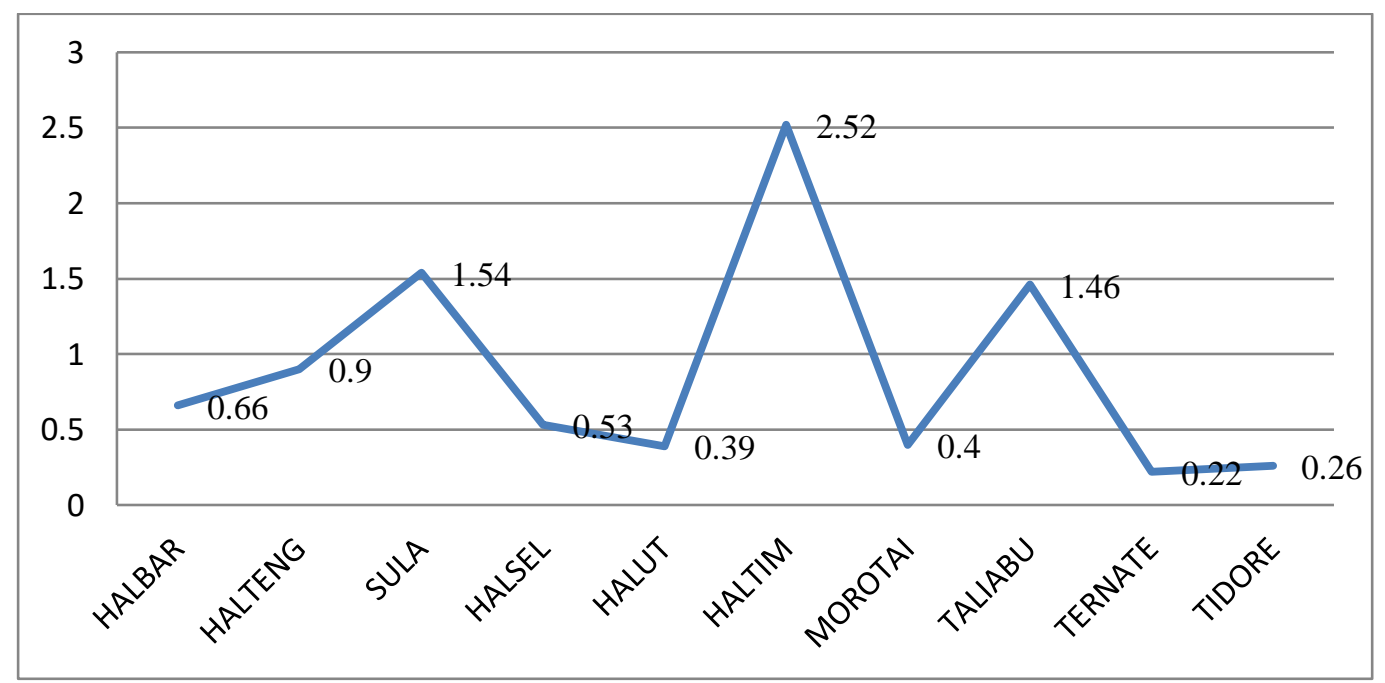

\section{Gambar 1 Grafik Indeks Kedalaman Kemiskinan di Provinsi Maluku Utara Tahun 2016} Sumber: BPS Provinsi Maluku Utara (2017).

Berdasarakan data pada grafik 1 di atas menunjukkan bahwa di Kabupaten / Kota di Provinsi Maluku Utara kemiskinan tertinggi berada di Kabupaten Halmahera Timur, yakni sebesar 2,52 persen, kemudian Kabupaten Kepulauan Sula yakni sebesar 1,54 persen. Sementara indeks kedalaman kemiskinan yang terendah berada di Kota Ternate, yakni sebesar 0,22 persen. 
Kemiskinan berpengaruh besar terhadap angka pengangguran. Salah satu cara untuk keluar dari lingkaran kemiskinan adalah dengan menawarkan diri untuk masuk kedalam pasar kerja, dengan bergabungnya seseorang dalam pasar kerja tentu saja kesejahteraan seseorang tersebut meningkat, sehingga seseorang tersebut bebas dari kemiskinan.

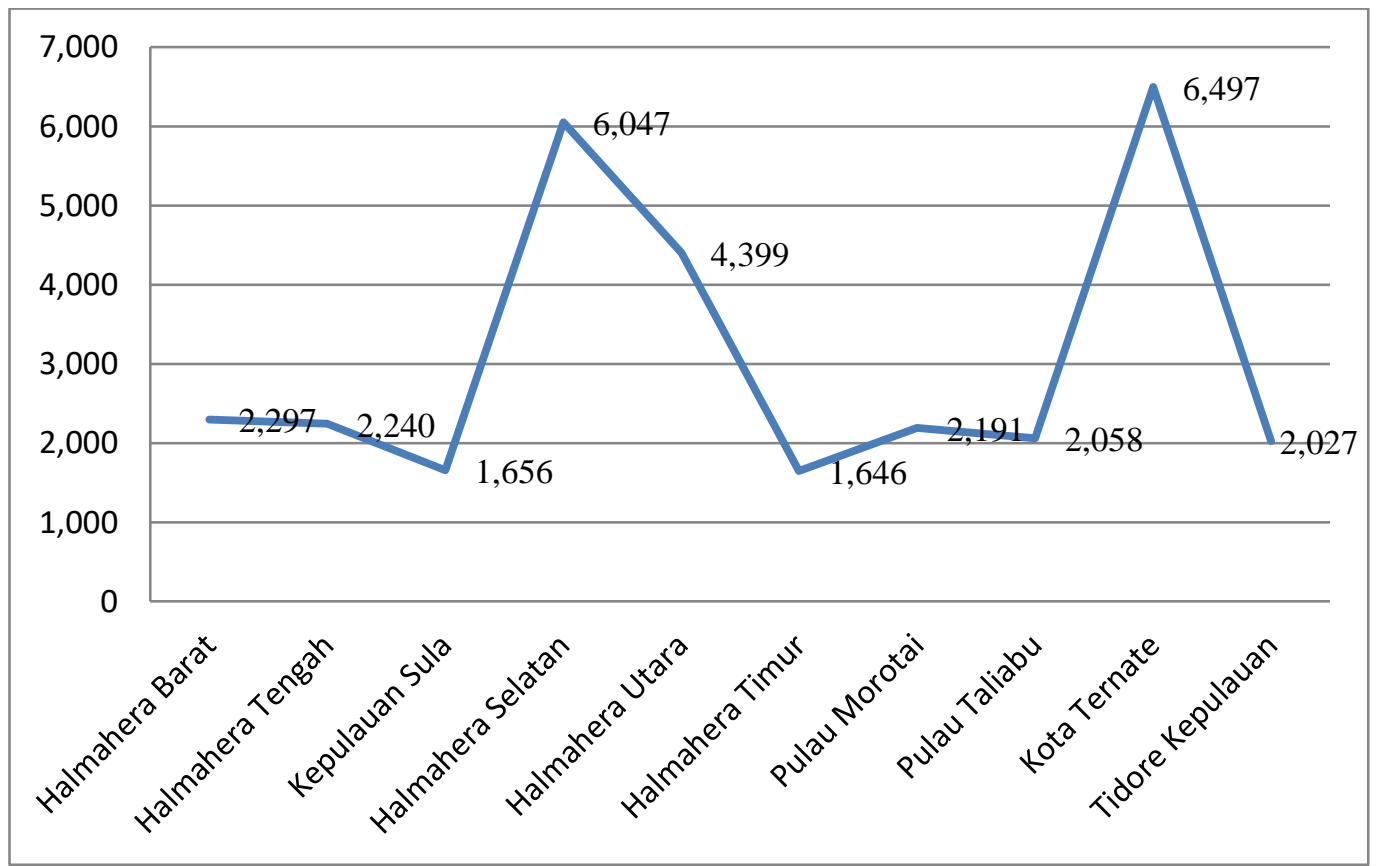

\section{Gambar 2 Grafik Pengangguran Terbuka di Provinsi Maluku Utara Tahun 2015} Sumber: BPS Provinsi Maluku Utara (2017)

Berdasarkan data pada grafik 2 di atas, menunjukkan bahwa tingkat pengangguran terbuka di kabupaten dan kota di Provinsi Maluku Utara Selanjutnya, jika dilihat dari sebaran penduduk di 10 (sepuluh) daerah Kabupaten/Kota di Provinsi Maluku Utara, tingkat pengangguran terbanyak berada di Kota Ternate yakni sebesar 6.497 jiwa dari total angkatan kerja 154.543 jiwa, dan penduduk yang bekerja sebanyak 88.034 jiwa. Kemudian yang berada pada peringkat kedua adalah Kabupaten Halmahera Selatan, dengan jumah pengangguran sebanyak 6.047 jiwa dari total angkatan kerja sebanyak 138.087 jiwa, dan penduduk yang bekerja sebanyak 89.714 jiwa (BPS; 2017).

Disamping pengangguran, Inflasi juga merupakan persoalan serius yang mempengaruhi perekonomian di negara indonesia. Meningkatnya harga secara umum dan terus-terus berdampak pada pemutusan hubungan kerja (PHK) sehingga menjadi penyebab bertambahnya angka pengangguran. Hal demikian menjadi juga momok yang menakutkan dan tidak dapat dihindari jika pemerintah berusaha mengurangi inflasi dan berusaha menekan harga. Karena inflasi berdampak pada perekonomian Indonesia, maka Pemerintah perlu membuat kebijakan untuk dapat mengatasi inflasi dan juga meminimalisir dan juga menghindari sebab terjadinya inflasi.

Data pada grafik 3 di bawah ini menunjukkan bahwa tingkat inflasi yang terjadi di Provinsi Maluku Utara cenderung fluktuatif. Kenaikan harga (inflasi) tertinggi terjadi pada bulan Juli 2016, yakni sebesar 1,04 persen, dan bulan Januari 2017 sebesar 0,63 persen. Walaupun demikian, Maluku Utara pernah mengalami deflasi pada bulan Agustus 2016 sebesar -0,1 persen dan bulan Maret 2017 sebesar -0,3 persen.

Berdasarkan latar belakang yang telah dikemukakan di atas, maka permasalahan penelitian ini adalah pakah tingkat inflasi berpengaruh terhadap tingkat pengangguran dan 
tingkat inflasi berpengaruh terhadap tingkat kemiskinan, juga apakah tingkat pengangguran berpengaruh terhadap tingkat kemiskinan di Provinsi Maluku Utara?

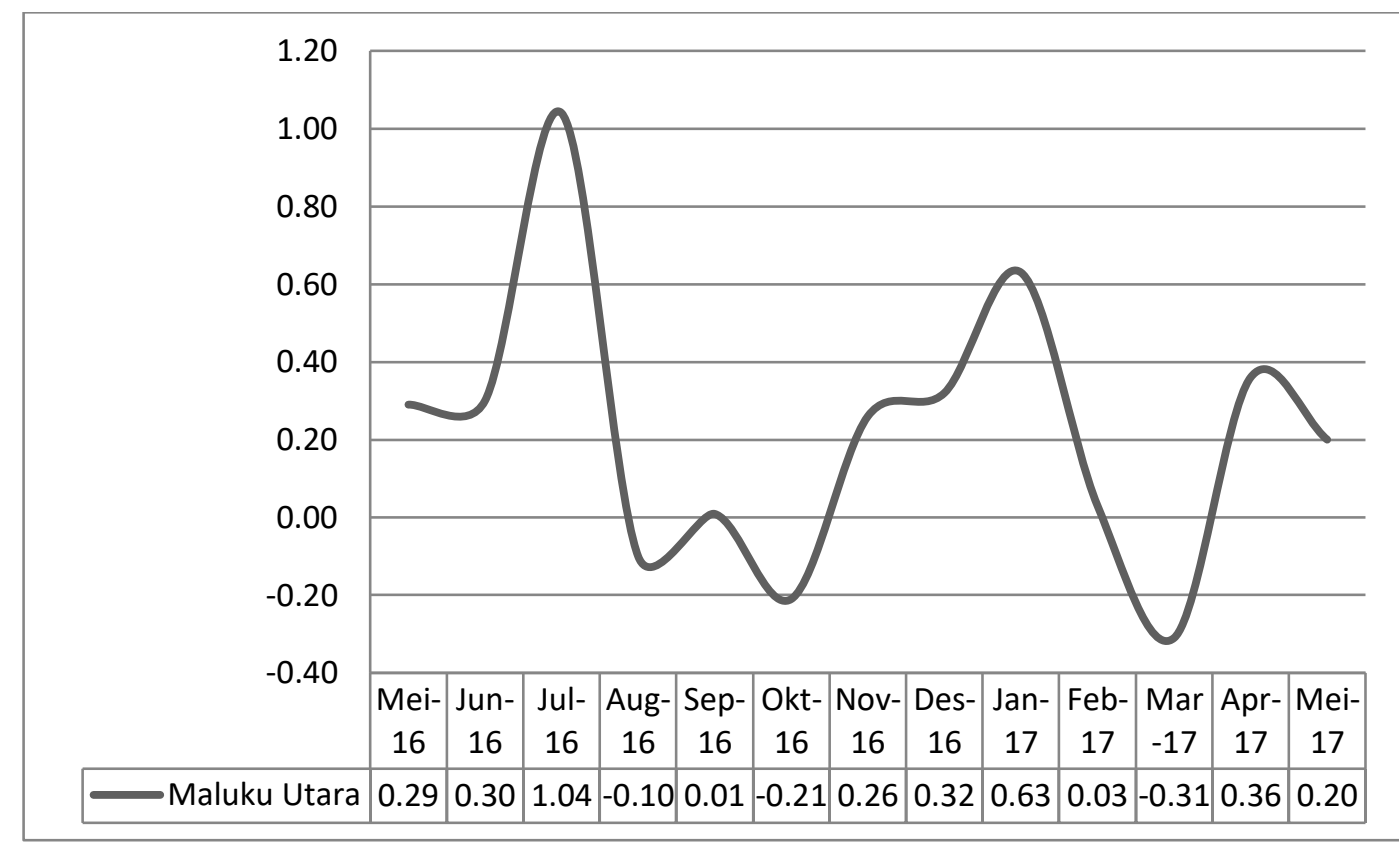

\section{Gambar 3 Grafik Perkembangan Tingkat Inflasi di Provinsi Maluku Utara Tahun 2016-2017}

Sumber: BPS Provinsi Maluku Utara, 2017.

Angka kemiskinan dan pengangguran biasa digunakan untuk melihat bagaimana tingkat kesejahteraan masyarakat. Suatu negara dapat menghasilkan dampak negatif terhadap perekonomian negara disebabkan oleh tingginya tingkat pengangguran. Biasanya mereka yang dikategorikan miskin (the poor) tidak memiliki pekerjaan (pengangguran) karena juga bekaitan dengan keterbatasan pekerjaan. Pengangguran erat kaitannya dengan kemiskinan. Karena masih banyaknya masyarakat yang menganggur menyebabkan masalah kemiskinan terus meningkat. Angka kemiskinan selalu ada disebabkan oleh sebagian masyarakat masih banyak meganggur sehingga sulitnya dalam memenuhi kebutuhan hidupnya (Yudha, 2013).

Tingkat inflasi dapat memiliki hubungan positif atau negatif terhadap besarnya jumlah pengangguran yang terjadi. Peningkatan pada inflasi akan menyebabkan peningkatan jumlah pengangguran. Hal ini terjadi sebagai akibat dari peningkatan pada tingkat inflasi akan menurunkan tingkat dan investasi, Akibatnya jumlah pengangguran meningkat seiring kesempatan kerja yang rendah. Di samping itu, menurut teori A.W. Phillips inflasi memberikan pengaruh positif terhadap jumlah pengangguran. Hal ini terjadi karena didasarkan pada asumsi bahwa inflasi merupakan cerminan dari adanya kenaikan permintaan agregat. Dengan naiknya permintaan agregat, berdasarkan teori permintaan, permintaan naik, harga akan naik pula. Dengan tingginya harga (inflasi) maka untuk memenuhi permintaan tersebut produsen meningkatkan kapasitas produksinya dengan menambah tenaga kerja (tenaga kerja merupakan satu-satunya input yang dapat meningkatkan output). Akibat dari peningkatan permintaan tenaga kerja, maka dengan naiknya harga-harga (inflasi) pengangguran akan berkurang.

Sedangkan tingkat upah merupakan salah satu faktor yang mempengaruhi tingkat pengangguran. Upah merupakan kompensasi yang diterima oleh satu unit kerja berupa jumlah uang yang dibayarkan. Upah tenaga kerja sangat penting untuk kedua belah pihak. 
Bagi pihak produsen, upah merupakan biaya produksi yang harus ditekan seefisien mungkin. Bagi pihak pekerja, upah merupakan sumber penghasilan bagi dirinya, keluarganya dan menjadi sumber pembelanjaan masyarakat. Tinggi rendahnya upah merupakan faktor penting yang menentukan taraf hidup masyarakat.Mengikuti konsep pemikiran di atas maka model penelitian yang diajukan dalam penelitian ini ditunjukkan pada gambar berikut.

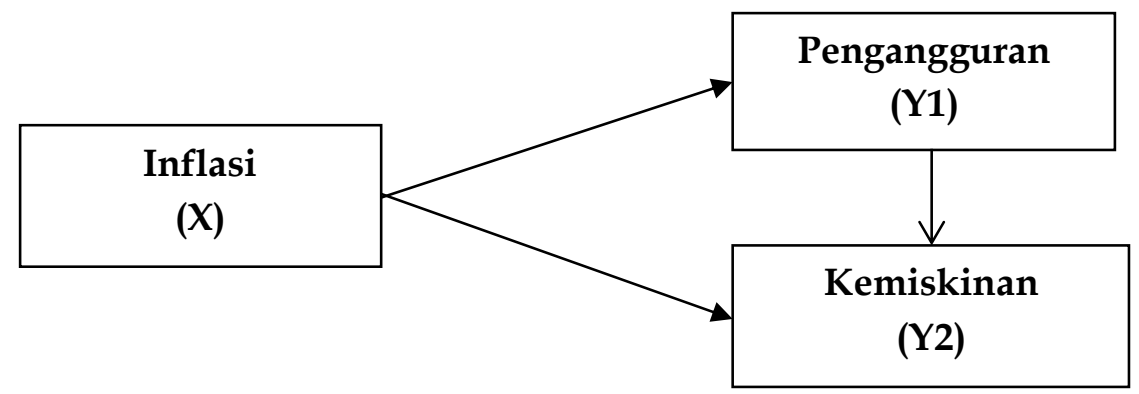

Gambar 4 Model Penelitian

\section{METODE PENELITIAN}

Provinsi Maluku Utara sebagai salah satu provinsi kepulauan, wilayah ini memiliki karakteristik dan potensi sumberdaya alam baik laut dan daratan yang besar. Namun faktanya potensi ini belum secara maksimal dikelola dan dimanfaatkan oleh pemerintah daerah dan sektor swasta sehingga dapat menciptakan lapangan kerja dan sekaligus dapat mengurangi tingkat pengangguran dan kemiskinan. Atas dasar pertimbangan inilah maka pemilihan Provinsi Maluku Utara sebagai daerah penelitian dianggap cukup representatif. Data yang digunakan dalam analisis meliputi data kuantitatif, dengan data sekunder yang meliputi data tentang tingkat inflasi, pengangguran, dan kemiskinan. Sumber data sekunder adalah instansi-instansi terkait, antara lain Bappeda, BKPM, Dinas Tenaga Kerja dan Badan Pusat Statistik (BPS) Provinsi Maluku Utara, serta laporan-laporan yang terkait dengan penelitian ini.

Penelitian ini menggunakan data runtun waktu (time series) tahun 2013-2018 dan menggunakan analisis jalur (path analysis). Analisis jalur digunakan untuk menjelaskan pola hubungan antar variabel dengan variabel perantara (variabel intervening) dengan tujuan untuk mengetahui pengaruh langsung maupun tidak langsung dari seperangkat variabel bebas (eksogen) terhadap variabel terikat (endogen). Dengan persamaan sebagai berikut:

$$
\begin{array}{lll}
\text { Ket: } & \mathrm{X} & =\text { Tingkat Inflasi } \\
\mathrm{Y}_{1} & =\text { Pengangguran } \\
\mathrm{Y}_{2} & =\text { Kemiskinan } \\
& \beta_{1} \ldots \beta_{3}=\text { Koefisien regresi variabel independen }\left(\mathrm{X}_{\mathrm{i}}\right) \\
\beta_{0} & =\text { Intercept } / \text { Konstanta } \\
\varepsilon_{1} & =\text { Error dari persamaan pertama } \\
\varepsilon_{2} & =\text { Error dari persamaan kedua }
\end{array}
$$

Inflasi $(X)$ adalah kecenderungan naiknya harga barang dan jasa secara terus menerus, ini menunjukkan bahwa terlalu banyak uang yang mengejar barang yang terbatas jumlahnya, dan dinyatakan dalam persentase. Tingkat pengangguran $\left(\mathrm{Y}_{1}\right)$ adalah yaitu jumlah penduduk yang menganggur, yang termasuk angkatan kerja namun tidak melakukan pekerjaan atau sedang mencari kerja. Variabel jumlah pengangguran yang digunakan adalah jumlah 
pengangguran terbuka di Indonesia, dengan menggunakan data dari BPS yaitu data orang usia (15 tahun keatas) yang mencari pekerjaan, mempersiapkan usaha, tidak mencari pekerjaan, belum memulai bekerja. Data yang diambil bersifat tahunan, dari tahun 2013 sampai 2018 dan satuan yang digunakan adalah jiwa/orang. Kemiskinan $\left(\mathrm{Y}_{2}\right)$ merupakan kondisi absolut atau relatif, yaitu keadaan seseorang atau kelompok masyarakat dalam suatu wilayah karena sebab-sebab natural, kultural, atau struktural menyebabkan seseorang atau kelompok tersebut tidak mempunyai kemampuan untuk mencukupi kebutuhan dasarnya, yang dinyatakan dalam satuan jiwa/orang.

\section{HASIL DAN PEMBAHASAN}

Berdasarkan data yang diperoleh, kemudian dilakukan penghitungan atau pengolahan data dengan menggunakan program SPSS. Adapun ringkasan hasil dari analisis jalur tersebut adalah sebagai berikut:

Tabel 1 Ringkasan Hasil Analisis Jalur

\begin{tabular}{cccccc}
\hline $\begin{array}{c}\text { Pengaruh antar } \\
\text { variabel }\end{array}$ & $\begin{array}{c}\text { Koefisien } \\
\text { Jalur } \\
\text { Beta }\end{array}$ & Nilai t & Nilai F & $\begin{array}{c}\text { Koefisien } \\
\text { Determinasi } \\
\left.\mathbf{( R}^{2}\right)\end{array}$ & Keterangan \\
\hline $\mathrm{X}$ terhadap $\mathrm{Y}_{1}$ & 0.001 & 6.976 & 78.89 & 0.939 & Signifikan \\
\hline $\mathrm{X}$ terhadap $\mathrm{Y}_{2}$ & 0.008 & 2.294 & 78.89 & 0.939 & Signifikan \\
\hline $\mathrm{Y}_{1}$ terhadap $\mathrm{Y}_{2}$ & 0.001 & 7.184 & 29.89 & 0.928 & Signifikan \\
\hline
\end{tabular}

Sumber: Data hasil olahan, 2018.

Berdasarkan tabel diatas mendeskripsikan bahwa pada model regresi persamaan pertama dengan pengujian secara individual (parsial), tingkat inflasi terhadap pengangguran, yaitu dimana pada tabel diperoleh nilai coefficients $\mathrm{t}$ sebesar 6.976 dengan nilai (sig) 0,032 karena nilai sig < 0,005 nilai probabilitas, maka keputusan $\mathrm{H}_{0}$ ditolak dan $\mathrm{H}_{\mathrm{a}}$ diterima artinya tingkat inflasi berpengaruh signifikan dan berkolerasi positif terhadap pengangguran di Provinsi Maluku Utara. Untuk model regresi kedua dengan pengujian secara individual (parsial), Tingkat inflasi terhadap kemiskinan, dimana pada tabel coefficients diperoleh nilai $\mathrm{t}$ sebesar 2,294 dengan nilai (sig) 0,001 karena nilai sig < 0,05 nilai probabilitas, maka keputusan $\mathrm{H}_{0}$ ditolak dan $\mathrm{H}_{\mathrm{a}}$ diterima artinya tingkat inflasi signifikan dan berkolerasi positif terhadap kemiskinan di Provinsi Maluku Utara.

Selanjutnya, pengaruh pengangguran terhadap kemiskinan dimana pada tabel coefficients diperoleh nilai t sebesar 7,184 dengan nilai (sig) 0,002 karena nilai sig < 0,05 nilai probabilitas, maka keputusan $\mathrm{H}_{0}$ diolak dan $\mathrm{H}_{\mathrm{a}}$ diterima artinya pengangguran berpengaruh signifikan dan berkolerasi positif terhadap kemiskinan di Provinsi Maluku Utara. Pada model regresi persamaan kedua dengan pengujian secara keseluruhan (simultan), tingkat inflasi dan pengangguran secara bersama terhadap kemiskinan yaitu dilihat pada tabel diperoleh nilai $\mathrm{F}$ sebesar 78,89 dengan nilai (sig) 0,001 karena nilai sig < 0,05 nilai probabilitas, maka keputusan $\mathrm{H}_{0}$ ditolak dan $\mathrm{H}_{\mathrm{a}}$ diterima artinya tingkat inflasi dan pengangguran secara bersama-sama terhadap kemiskinan adalah bepengaruh signifikan dan berkolerasi positif.

Berdasarkan hasil penelitian menunjukkan bahwa tingkat inflasi berpengaruh signifikan dan berkorelasi positif terhadap pengangguran di Provinsi Maluku Utara. Artinya bahwa, jika terjadi kenaikan dalam tingkat inflasi maka akan terjadi peningkatan jumlah pengangguran. Hal ini disebabkan kenaikan tingkat inflasi yang diakibatkan naiknya harga kebutuhan pokok masyarakat dan pemerintah juga akan menyesuaikan upah minimum regional (UMR) sehingga pihak swasta cenderung tidak melakukan permintaan tenaga kerja. Selain itu, kenaikan inflasi menyebabkan naiknya suku bunga sehingga akan menghambat 
investasi. Hasil penelitian ini tidak sejalan dengan penelitian terdahulu Algofari (2010), yang menemukan bahwa tidak ada pengaruh inflasi terhadap pengangguran di Indonesia. Naik turunnya inflasi tidak akan menyebabkan naik turunnya pengangguran di Indonesia. Namun, sejalan dengan penelitian yang dilakukan oleh Dinarno dan Mark P. Moore (1999), dimana penelitian ini dihasilkan adanya hubungan yang positif antara tingkat inflasi melalui GDP Deflator dengan tingkat pengangguran yang terjadi. Semakin tinggi tingkat inflasi yang terjadi di suatu negara maka akan berdampak pada tingginya tingkat pengangguran yang ditimbulkannya.

Berdasarkan hasil penelitian menunjukkan bahwa tingkat inflasi berpengaruh signifikan dan berkorelasi positif dengan kemiskinan di Provinsi Maluku Utara. Artinya bahwa, jika terjadi kenaikan tingkat inflasi maka akan terjadi peningkatan jumlah masyarakat miskin. Hasil penelitian ini hamper sejalan dengan penelitian Sembiring (2011) dalam penelitiannya yang berjudul "Analisis Determinan Tingkat Kemiskinan Penduduk Kabupaten Karo di Sumatera Utara". Hasil penelitiannya menyimpulkan bahwa anggaran kesehatan berpengaruh negatif terhadap jumlah penduduk miskin, sedangkan inflasi, pengangguran, dan pajak daerah berpengaruh positif terhadap jumlah penduduk miskin di Kabupaten Karo. Namun demikian penelitain ini tidak sejalan dengan penelitian Amir (2007), dimana pengaruh pertumbuhan ekonomi dan inflasi terhadap pengangguran di Indonesia, dengan menggunakan data periode 1980-2005 menyimpulkan bahwa pertumbuhan ekonomi meningkat $1 \%$, maka pengangguran akan menurun sekitar $0.46 \%$, sedangkan inflasi terbukti tidak ada pengaruh yang nyata terhadap penurunan jumlah penduduk miskin. Penelitian Mustamin, dkk (2015) juga menemukan, tingkat inflasi tidak berpengaruh terhadap tingkat kemiskinan. Artinya, naiknya tingkat inflasi akan menurunkan tingkat kemiskinan yang secara statistik variabel inflasi mempunyai efek langsung terhadap kemiskinan sebesar -0,088. Hal ini berarti setiap kenaikan inflasi sebesar 1 persen diikuti penurunan kemiskinan sebesar 0,088 persen dengan tingkat signifikansi 5 persen.

Kebijakan pemerintah Indonesia terkait dengan masalah menanggulangi kemiskinan dan pengangguran terkesan tidak efektif belum benar-benar menyentuh ke elemen masyarakat kecil yang benar-benar membutuhkan. Sehubungan dengan itu perlu kiranya melakukan reformasi ekonomi. Tidak sedikit para penentu kebijakan (Birokrat) dengan dukungan informasi dari pakar-pakar ekonomi memandang bahwa masalah kemiskinan dan pengangguran akan terpecahkan manakala ekonomi tumbuh dengan laju tinggi. Jika pandangan ini dianggap "benar" sekiranya akan membutuhkan waktu yang panjang. Sedangkan kemiskinan dan khususnya pengangguran bergerak bagaikan deret kali.

Berdasarkan hasil penelitian menunjukkan bahwa inflasi dan pengangguran berpengaruh signifikan dan berkorelasi positif terhadap kemiskinan di Provinsi Maluku Utara. Artinya bahwa, jika terjadi kenaikan pada tingkat inflasi dan pengangguran maka akan meningkatkan jumlah penduduk miskin di Provinsi Maluku Utara. Hasil penelitian ini sejalan dengan penelitian Cutler \& Katz (1991) yang menemukan hubungan yang kuat antara kemiskinan dengan berbagai variabel ekonomi makro. Penelitian-penelitian tersebut juga membuktikan bahwa tingkat pengangguran dan inflasi keduanya berhubungan positif dengan jumlah penduduk yang berada di bawah garis kemiskinan; semakin tinggi tingkat inflasi dan pengangguran semakin besar tingkat kemiskinan. Pengangguran memiliki pengaruh yang kuat terhadap tingkat kemiskinan sementara inflasi hanya memberikan pengaruh yang relatif kecil.

Hoover \& Wallace (2003), menemukan bahwa tingkat kemiskinan sangat sensitif terhadap kondisi ekonomi, dimana peningkatan pengangguran menyebabkan peningkatan kemiskinan. Hal ini sesuai dengan penelitian yang dilakukan oleh Alit dan Sudiana (2013), pada penelitian tersebut menyatakan bahwa apabila pengangguran meningkat maka angka kemiskinan pun akan meningkat pula. Hal tersebut juga sesuai dengan penelitian yang 
dilakukan oleh Sukmaraga (2011), pada penelitian ini menyatakan kenaikan pengangguran akan menyebabkan meningkatnya tingkat kemiskinan pada daerah tersebut.

\section{SIMPULAN}

Berdasarkan hasil penelitian dan pembahasan sebelumnya, maka kesimpulan penelitian ini yakni tingkat inflasi berpengaruh signifikan dan berkorelasi positif terhadap pengangguran di Provinsi Maluku Utara. Kenaikan tingkat inflasi menyebabkan naiknya suku bunga sehingga menghambat investasi (Crowding out Investment) yang berdampak pada terjadinya peningkatan dalam jumlah pengangguran. Selain itu, kenaikan inflasi menyebabkan pemerintah harus menyesuaikan / menaikan upah minimum regional (UMR) sehingga berakibat pada tidak adanya permintaan tenaga kerja. Tingkat inflasi berpengaruh signifikan dan berkorelasi positif terhadap kemiskinan di Provinsi Maluku Utara. Semakin tinggi tingkat inflasi maka kemampuan atau daya beli masyarakat akan menurun, sehingga menjadi miskin. Inflasi mengakibatkan nilai riil dari uang yang dipegang menjadi turun. Ketika harga meningkat, uang untuk membeli lebih sedikit (daya beli menjadi turun). Tingkat inflasi dan pengangguran berpengaruh signifikan dan berkorelasi positif terhadap kemiskinan di Provinsi Maluku Utara. Semakin tinggi tingkat inflasi dan pengangguran semakin besar tingkat kemiskinan. Pengangguran memiliki pengaruh yang kuat terhadap tingkat kemiskinan sementara inflasi hanya memberikan pengaruh yang relatif kecil. Selanjutnya, berdasarkan kesimpulan yang dikemukakan, maka saran penelitian ini adalah inflasi berpengaruh positif terhadap pengangguran di Provinsi Maluku Utara, yang disebabkan terjadi ketidakseimbangan antara permintaan dan penawaran tenaga kerja. Oleh karena itu, diperlukan kebijakan pemerintah dalam menjaga stabilitas harga agar tidak mengganggu kegiatan-kegiatan sektor swasta yang pada gilirannya dapat menyerap tenaga kerja. Kebijakan yang dapat dilakukan pemerintah adalah dengan menaikan suku bunga sehingga mengurangi perputaran uang dan mendorong produksi di sektor swasta. Inflasi berpengaruh positif terhadap kemiskinan di Provinsi Maluku Utara, yang disebabkan dengan terjadinya kenaikan dalam tingkat inflasi maka akan menurunkan nilai uang yang dipegang masyarakat sehingga menurunkan daya beli. Oleh karena itu, pemerintah perlu melakukan kebijakan dalam penanggulangan kemiskinan melalui penciptaan lapangan kerja serta menjaga kestabilan harga terutama harga-harga kebutuhan pokok masyarakat. Inflasi dan pengangguran berpengaruh positif terhadap kemiskinan di Provinsi Maluku Utara. Kenaikan inflasi menyebabkan naiknya suku bunga sehingga menghambat investasi yang berdampak pada pengangguran yang pada gilirannya menaikkan jumlah penduduk miskin. Oleh karena itu, inflasi dan pengangguran menjadi permasalahan utama yang harus diprioritaskan pemerintah. Kebijakan fiskal ekspansif diharapkan dapat mendorong kegiatan swasta dan investasi serta mendorong produksi masyarakat di dalam daerah sehingga dapat menjaga meningkatkan pendapatan dan menjaga keseimbangan harga. Bagi peneliti lain, agar dapat mengkaji persoalan kemiskinan dan pengangguran dengan melihat pada sektor-sektor ekonomi. Selain itu dapat menambah variabel penelitian seperti tingkat upah, investasi, dan pertumbuhan ekonomi agar dapat memperoleh informasi yang lebih komprehensif terkait dengan pengangguran dan kemiskinan yang terjadi di Provinsi Maluku Utara.

\section{DAFTAR PUSTAKA}

Amalia, Fitri. 2012. Pengaruh Pendididkan, Pengangguran dan Inflasi Terhadap Tingkat Kemiskinan di Kawasan Timur (KTI) Periode 2001-2010. EconoSains. Vol.X,No.2 2012.

Amir, Amri. 2007. Pengaruh Inflasi dan pertumbuhan Ekonomi Terhadap Penganggurandi Indonesia (online), http://amriamir.wordspress.com. Diakses tanggal 5 Pebruari 2019.

Alghofari, F. 2010. Analisis Tingkat Pengangguran di Indonesia Tahun 1980-2007. Skripsi. Fakultas Ekonomi Universitas Diponegoro. Semarang. 
Alit, Wira Dyatmika A.A. Gde dan Ketut Sudiana. 2013. Pengaruh Jumlah Penduduk, Jumlah Penyerapan Tenaga Kerja dan Pengangguran Terhadap Jumlah Penduduk Miskin di Kabupaten Buleleng. E-Jurnal Ekonomi Pembangunan. Vol. 2, No. 7, Juli 2013, Fakultas Ekonomi dan Bisnis Universitas Udayana.

Cutler, David M. dan Lawrence F. Katz. 1991. Macroeconomic Performance and the Disadvantaged. Brookings Paper on Economic Activity, Vol.1 No.2, hal.1-74.

Dinarno, John And Moore, P. Mark. 1999. Philips Curve. Journal, Vol. 1, No1.

Hoover, Gary A. dan Geoffrey L. Wallace. 2003. Examining the Relationship between the Poverty Rate and Economic Conditions: A Comparison of the 1980s-1990s".The University of Alabama. Economic, Finance and Legal Working Paper Series.Oktober 2003.

Jonaidi, Arius. 2012. Analisis Pertumbuhan Ekonomi dan Kemiskinan di Indonesia. Jurnal Kajian Ekonomi. Vol 1, No 1.

Mustamin, dkk. 2015. Pengaruh Variabel Ekonomi Makro Terhadap Kemiskinan di Kota Makassar Provinsi Sulawesi Selatan. Jurnal Analisis. Desember 2015, Vol. 4 No. 2 : 165173

Sembiring, Sodes. 2011. Analisis Determinan Tingkat Kemiskinan Penduduk Kabupaten Karo Di Sumatera Utara. Tesis. Pasca Sarjana Universitas Sumatera Utara.

Sukmaraga, Prima. 2011. Analisis Pengaruh Indeks Pembangunan Manusia, PDRB Per Kapita, dan Jumlah Pengangguran Terhadap Jumlah Penduduk Miskin Di Provinsi Jawa Tengah. Semarang; Skripsi. Fakultas Ekonomi Universitas Diponegoro.

Vincent, Brian. 2009. The Concept 'Poverty' towards Understanding in the Context of Developing Countries 'Poverty qua Poverty'. Journal of Sustainable Development, 2(2).

Yudha, Okta Ryan Pranata. 2013. Pengaruh Pertumbuhan Ekonomi, Upah Minimum, Tingkat Pengangguran Terbuka, dan Inflasi terhadap Kemiskinan di Indonesia Tahun 2009-2011. Skripsi. Jurusan Ekonomi Pembangunan Fakultas Ekonomi Universitas Negeri Semarang. 